\title{
Sistem Pendukung Keputusan Penentuan Gaji Bonus Karyawan Pada Restoran KL Express Dengan Metode TOPSIS
}

\author{
Dwija Wisnu Brata ${ }^{1}$, Bayu Whidyanto ${ }^{2}$ \\ STMIK ASIA MALANG \\ 1'wbrata@gmail.com,2bayu@gmail.com
}

\begin{abstract}
ABSTRAK. Pemberian gaji bonus terkadang menjadi suatu kendala bagi sebuah restoran, dikarenakan suatu restoran dihadapkan pada sebuah keputusan yaitu kepada siapa pemberian gaji bonus ini diberikan. Untuk itu diperlukan sebuah sistem yang dapat membantu pengambilan keputusan untuk memecahkan permasalahan tersebut. Pada penelitian ini dirancang sistem pendukung keputusan pemberian gaji bonus dengan metode topsis yang dimaksud agar dapat membantu pihak terkait untuk memberikan solusi pemberian gaji bonus. Sistem Pendukung keputusan (DSS) adalah bagian dari sistem informasi berbasis komputer (termasuk sistem berbasis pengetahuan) yang dipakai untuk mendukung pengambilan keputusan dalam suatu organisasi atau perusahaan.Sedangkan metode Technique for Order Preferense by Similarity to Ideal Solution (TOPSIS) adalah didasarkan pada konsep dimana alternatif terpilih yang terbaik tidak hanya memiliki jarak terpendek dari solusi ideal positif, namun juga memiliki jarak terpanjang dari solusi ideal negatif.Hasil pengujian dari aplikasi dengan menggunakan metode topsis mampu menyeleksi alternatif terbaik, dalam hal ini alternatif yang dimaksud yaitu karyawan yang berhak menerima gaji bonus berdasarkan kriteria-kriteria yang ditentukan. Hasil dari perhitungan manual dan sistem aplikasi adalah sama.
\end{abstract}

Kata Kunci: SPK, Bonus Karyawan, TOPSIS

\section{PENDAHULUAN}

Gaji bonus adalah pembayaran tambahan di luar upah atau gaji yang ditujukan untuk memacu (memberi insentif) agar pekerja dapat menjalankan tugasnya lebih baik dan penuh tanggungjawab, dengan harapan keuntungan lebih tinggi. Makin tinggi keuntungan yang diperoleh makin besar bonus yang diberikan pada pekerja.Tidak semua perusahaan di Indonesia memberikan gaji bonus kepada karyawan. Gaji bonus ini biasanya dikeluarkan atas inisiatif dari pemimpin perusahaan.Pada penelitian yang dilakukan, studi kasus mengambil tempat di KL Express Resto. Pemberian gaji bonus yang terdapat pada KL Express dilakukan setiap akhir bulan dan diberikan kepada satu karyawan. Hal ini juga masih dilakukan secara manual dan membutuhkan waktu dalam menentukan karyawan yang mendapatkan bonus. Penelitian yang dilakukan mencoba untuk memberikan suatu bantuan rekomendasi secara otomatis dan memotong waktu yang lama. Topsis menjadi salah satu metode yang digunakan sebagai penentuan rekomendasi karyawan yang akan diberi gaji bonus. Terdapat kriteria yang menjadi acuan penelitian yang akan digunakan dalam metode topsis, yaitu adalah absensi,jumlah lembur dalam satu bulan, kerajinan, pelayanan terhadap customer.Hasil dari metode yang digunakan adalah perangkingan, hal ini menjadi masukan kepada pengambil keputsan KL Express Resto untuk melihat nilai yang tertinggi berdasarkan kriteria nilai yang telah dimasukkan.

\section{LANDASAN TEORI}

\subsection{Pengertian Gaji}

Menurut Rokmulyati (1983) menyatakan bahwa gaji merupakan suatu bentuk pembayaran periodik dari seorang majikan pada karyawan yang dinyatakan dalam suatu kontrak kerja. Dari sudut pandang pelaksanaan bisnis, gaji dapat dianggap sebagai biaya yang dibutuhkan untuk mendapatkan sumber daya manusia untuk menjalankan operasi, dan karenanya disebut dengan biaya personel atau biaya gaji. Dalam akuntansi, gaji dicatat dalam akun gaji. Istilah lain dari gaji adalah honor dan upah. Gaji, honor ataupun upah dapat diterima pegawai di lingkungan kantor atau tempat kerja milik negara atau tempat swasta.

\subsection{Macam Pemberian Upah di Indonesia}

\subsubsection{Upah Menurut Waktu}

Menurut Rokmulyati (1983)besarnya upah didasarkan pada lama bekerja seseorang. Satuan waktu dihitung per jam, per hari, per minggu atau per bulan. Misalnya pekerja bangunan dibayar per hari atau per minggu. 


\subsubsection{Upah Menurut Satuan Hasil}

Menurut Rokmulyati (1983)besarnya upah didasarkan pada jumlah barang yang dihasilkan oleh seseorang. Satuan hasil dihitung per potong barang, per satuan panjang, atau per satuan berat. Misalnya upah pemetik daun teh dihitung per kilogram.

\subsubsection{Upah Borongan}

Menurut Rokmulyati (1983)pembayaran upah berdasarkan atas kesepakatan bersama antara pemberi dan penerima pekerjaan. Misalnya upah untuk memperbaiki mobil yang rusak, membangun rumah, dll. Upah model ini harus jelas bukan hanya besarnya upah yang disepakati, tetapi juga berapa lama pekerjaan yang ditugaskan kepada penerima borongan harus selesai.

\subsubsection{Sistem Bonus}

Menurut Hasibuan (1999) mendefinisikan upah insentif adalah balas jasa yang diberikan kepada karyawan tertentu yang prestasinya di atas prestasi standart. Sistem bonus adalah pembayaran tambahan di luar upah atau gaji yang ditujukan untuk merangsang (memberi insentif) agar pekerja dapat menjalankan tugasnya lebih baik dan penuh tanggungjawab, dengan harapan keuntungan lebih tinggi. Makin tinggi keuntungan yang diperoleh makin besar bonus yang diberikan pada pekerja.

\subsection{Pengertian Sistem}

Menurut Andi Kristanto (2003) menyatakan bahwa sistem adalah jaringan kerja dari prosedur-prosedur yang saling berhubungan, berkumpul bersama-sama untuk melakukansuatu kegiatan atau menyelesaikan suatu sasaran tertentu. Sistem dapat diartikan sebagai suatu kumpulan himpunan dari unsur yang terorganisasi saling berinteraksi, saling tergantung dan terpadu.

\subsection{Sistem Informasi Manajemen (SIM)}

Menurut Donald W. Kroeber (1984) mendefinisikan sistem informasi manajemen sebagai sejumlah proses dalam menyajikan informasi kepada para manajer yang digunakan untuk mendukung kegiatan operasional serta pengambilan sebuah keputusan didalam suatu organisasi.

Dengan kata lain SIM adalah sebagai suatu sistem berbasis komputer yang menyediakan informasi bagi beberapa pemakai dengan kebutuhan yang sama. Para pemakai biasanya membentuk suatu entitas organisasi formal, perusahaan atau sub unit dibawahnya. Informasi menjelaskan perusahaan atau salah satu sistem utamanya mengenai apa yang terjadi di masa lalu, apa yang terjadi sekarang dan apa yang mungkin terjadi di masa yang akan datang. Informasi tersebut tersedia dalam bentuk laporan periodik, laporan khusus dan ouput dari model matematika. Output informasi digunakan oleh manajer maupun non manajer dalam perusahaan saat mereka membuat keputusan untuk memecahkan masalah.

\subsection{Pengertian Sistem Pendukung Keputusan (SPK)}

Definisi SPK secara sederhana adalah sebuah sistem yang digunakan sebagai alat bantu menyelesaikan masalah untuk membantu pengambil keputusan (manajer) dalam menentukan keputusan tetapi tidak untuk menggantikan kapasitas manajer hanya memberikan pertimbangan. Turban (2005) menyatakan SPK ditujukan untuk keputusan-keputusan yang memerlukan penilaian atau pada keputusan-keputusan yang sama sekali tidak dapat didukung oleh algoritma. Definisi ini belum memberikan gambaran secara spesifik bahwa SPK berbasis komputer dan akan beroperasi online interakif, maka dari itu muncul berbagai definisi mengenai SPK.

Little (1970) mendefenisikan SPK sebagai sekumpulan prosedur berbasis model untuk data pemrosesan dan penilaian guna membantu para namajer mengambil keputusan. Dia menyatakan bahwa untuk sukses, sistem tersebut haruslah sederhana, cepat, mudah dikontrol, adaftif, lengkap dengan isu-isu penting, dan mudah berkomunikasi.

Bonczek (1980) mendefenisikan SPK sebagai sistem berbasis komputer yang terdiri dari tiga komponen yang saling berinteraksi: sistem bahasa (mekanisme untuk memberikan komunikasi antara pengguna dan komponen SPK lain), sitem pengetahuan (repositori pengetahuan domain masalah yang ada pada SPK baik sebagai data atau sebagai prosedur), dan sistem pemrosesan masalah (hubungan antara dua komponen lainnya, terdiri dari satu atau lebih kapabilitas manipulasi masalah umum yang diperlukan untuk pengambilan keputusan). Konsep-konsep yang diberikan oleh defenisi tersebut sangat penting untuk memahami hubungan antara SPK dan pengetahuan.

Keen (1980) menerapkan istilah SPK untuk situasi dimana sistem 'final' dapat dikembangkan hanya melalui sutau proses pembelajaran dan evolusi yang adaftif. Jadi, ia mendefinisikan SPK sebagai suatu produk dari proses pengembangan dimana pengguna SPK, pembangun SPK, dan SPK itu sendiri mampu mempengaruhi satu dengan yang lainnya, dan menghasilkan evolusi sistem dan pola-pola penggunaan.

Turban (2005) menyatakan definisi formal tentang SPK tidak memberikan fokus yang konsisten karena masing-masing defenisi berusaha mempersempit populasi secara berbeda-beda.

\subsection{Technique For Order Preference by Similarity to Ideal Solution (TOPSIS)}


TOPSIS adalah salah satu metode pengambilan keputusan multikriteria yang pertama kali diperkenalkan oleh Yonn dan Hwang pada tahun 1981. Dengan ide dasarnya adalah bahwa alternatif yang dipilih memiliki jarak terdekat dengan solusi ideal positif dan memiliki jarak terjauh dari solusi ideal negatif. Berikut ini adalah contoh sebuah matriks dengan alternatif dan kriteria.

Dimana:

$$
D=\left[\begin{array}{ccc}
x_{1} & \cdots & x_{1 n} \\
\vdots & & \vdots \\
x_{m 1} & \cdots & x_{m}
\end{array}\right]
$$

$\mathrm{D}=$ matriks

$\mathrm{m}=$ alternative

$\mathrm{n}=$ kriteria

\subsubsection{Procedure TOPSIS}

$$
x_{\mathrm{L} .}=a l \quad k-i d \quad k r \quad k-l
$$

A. Normalisasi Matriks Keputusan

Setiap elemen pada matriks $D$ dinormalisasikan untuk mendapatkan matriks normalisasi $R$. Setiap normalisasi dari nilai $r_{\mathrm{L}}$ dapat dilakukan dengan perhitungan sebagai berikut:

Untuk $\mathrm{i}=1,2,3, \ldots, m$;

$$
r_{\mathrm{L} .}=\frac{s_{i}}{\sqrt{\sum_{i=1}^{m} \Delta_{i}^{L}}}
$$

$$
\mathrm{j}=1,2,3, \ldots, n
$$

B. Pembobotan Pada Matriks Yang Telah Dinormalisasikan

Diberikan bobot $\mathrm{W}=(\mathrm{w} 1, \mathrm{w} 2, \ldots, \mathrm{wn})$, sehingga weighted normalized matrix $\mathrm{V}$ dapat dihasilkan sebagai berikut:

$$
\nu=\left[\begin{array}{ccccc}
W_{1} & r_{1} & \ldots & W_{1 n} r_{1 n} \\
\vdots & & & \vdots \\
W_{m 1} & r_{m 1} & \ldots & W_{n} & r_{n}
\end{array}\right]
$$

Dengan $\mathrm{i}=1,2,3, \ldots, \mathrm{m}$ dan $\mathrm{j}=1,2,3 \ldots, \mathrm{n}$

C. Menentukan Solusi Ideal Positif Dan Solusi Ideal Negative

Solusi ideal positif dinotasikan dengan A+ dan solusi ideal negatif dinotasikan dengan A-, sebagi berikut :

Menentukan Solusi Ideal (+) \& (-)

$$
\begin{aligned}
& A^{+}=\left\{\left(\max v_{\mathrm{L}} \mid / \in J\right)\left(\min v_{\mathrm{L}} \mid / \in J^{\prime}\right), i=1,2,3, \ldots m\right\}=\left\{v_{1}^{+}, v_{2}^{+}, \ldots v_{m}^{+}\right\} \\
& A^{-}=\left[\left(\max v_{\mathrm{L}} \mid / \in J\right)\left(\min v_{\mathrm{L}} \mid / \in J^{\prime}\right), i=1,2,3, \ldots m\right\}=\left\{v_{1}^{-}, v_{4}^{-}, \ldots v_{m}^{-}\right\}
\end{aligned}
$$

Dimana :

$\mathrm{Vij} \quad=$ elemen matriks $\mathrm{V}$ baris ke-i dan kolom ke- $\mathrm{j}$

$\mathrm{J}=\{\mathrm{j}=1,2,3, \ldots, \mathrm{n}$ dan $\mathrm{j}$ berhubung dengan benefit criteria $\}$

$\mathrm{J}^{\prime} \quad=\{\mathrm{j}=1,2,3, \ldots, \mathrm{n}$ dan $\mathrm{j}$ berhubung dengan cost criteria $\}$

D. Menghitung Jarak Setiap Alternatif dengan Matriks Solusi Ideal Positif dan Matriks Solusi Ideal Negatif (Separation Measure)

Separation measure ini merupakan pengukuran jarak dari suatu alternatif ke solusi ideal positif dan solusi ideal negatif. Perhitungan matematisnya adalah sebagai berikut:

Separation measure untuk solusi ideal positif

$$
L_{\mathrm{l}}^{+}=\sqrt{\sum_{j-1}^{\mathrm{n}}\left(y_{\mathrm{L}}-y_{j}^{+}\right)^{2}} \text {, dengan } \mathrm{i}=1,2,3, \ldots, \mathrm{n}
$$

Separation measure untuk solusi ideal negatif

$$
\nu_{\mathrm{c}}^{-}=\sqrt{\sum_{j-1}^{n}\left(y_{\mathrm{L}}-y_{j}^{-}\right)^{2}} \text {, dengan } \mathrm{i}=1,2,3, \ldots, \mathrm{n}
$$

E. Menghitung Kedekatan Relative dengan Ideal Positif

Kedekatan relative dari alternatif A+ dengan solusi ideal A- direpresentasikan dengan: 


$$
V_{\mathrm{l}}=\frac{D_{\bar{l}}^{-}}{D_{\bar{l}}^{-}+D_{l}^{\dagger}} d \quad 0<V_{\mathrm{l}}<1 d \quad i=, 2,3, \ldots, m
$$

F. Mengurutkan Pilihan

Alternatif dapat dirangking berdasarkan urutan C_i. Maka dari itu, alternatif terbaik adalah salah satu yang berjarak terpendek terhadap solusi ideal positif dan berjarak terjauh dengan solusi ideal negatif.

\section{METODE PENELITIAN}

\subsection{Analisis Kebutuhan Input}

Input yang digunakan untuk melakukan proses pengambilan keputusan dari beberapa alternatif adalah sebagai berikut.

Tabel 1. Analisis Kebutuhan Input

\begin{tabular}{|l|l|}
\hline No & Kriteria \\
\hline 1 & Kehadiran \\
\hline 2 & Jumlah lembur satu bulan \\
\hline 3 & Kerajinan \\
\hline 4 & Pelayanan terhadap customer \\
\hline
\end{tabular}

Tabel 1 menjelaskan bahwa proses keputusan dibutuhkan beberapa kriteria yaitu kehadiran, jumlah lembur dalam satu bulan, kerajinan dan pelayanan terhadap sehingga nantinya akan dihasilkan output yang berasal dari kelayakan alternatif yang dihasilkan dari proses perangkingan.

\subsection{Analisis Kebutuhan Output}

Output yang dihasilakan dari alternatif yang mempunyai nilai tertinggi dari pada nilai alternatif yang lain. Hasil yang dikeluarkan oleh program adalah nilai setiap kriteria yang ada, karena dalam setiap kriteria memiliki nilai yang berbeda dengan kriteria yang lainnya. Dan alternatif yang dimaksudkan adalah karyawan restoran KL EXRESS.

\subsection{Flowchart}

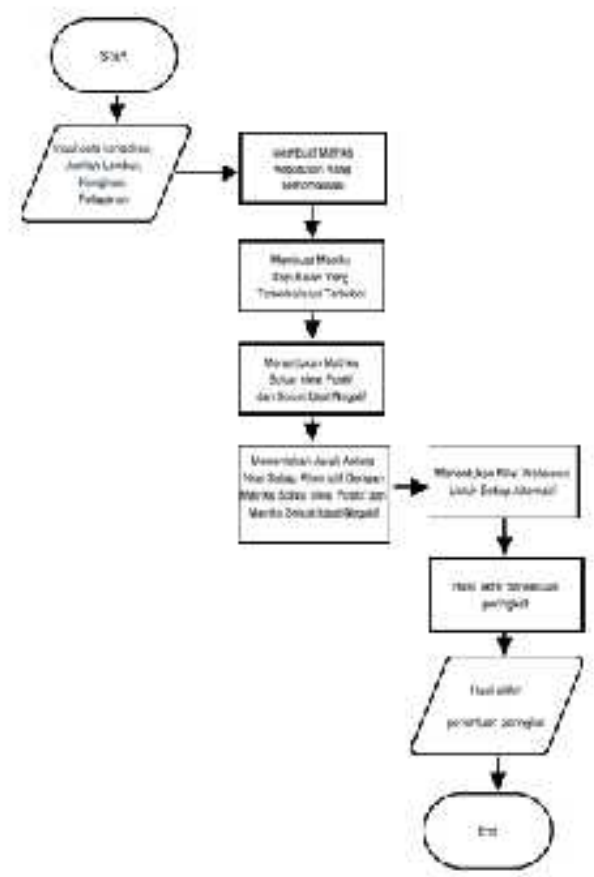

Gambar 1. Flowchart Metode Topsis 


\section{HASIL DAN PEMBAHASAN}

\subsection{Tampilan Menu Utama}

Form utama merupakan tampilan antarmuka yang pertama muncul ketika sistem ini dijalankan. Berikut adalah tampilan awal program, dapat dilihat pada gambar 2:

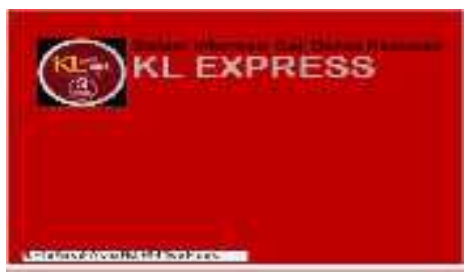

\subsection{Tampilan Form Proses}

Gambar 2. Form Menu Utama

Form Proses merupakan tampilan antarmuka tempat melakukan proses penyeleksian karyawan restoran KL Express. Form ini menjadi tempat kerja utama untuk melakukan langkah-langkah penyeleksian dengan metode TOPSIS.

Dalam proses seleksi karyawan terdapat dua command button yaitu button proses untuk melakukan proses seleksi dan button data untuk pindah ke form input data karyawan. Berikut tampilan antarmuka dari proses seleksi karyawan dengan metode TOPSIS, dapat dilihat pada gambar 3 :

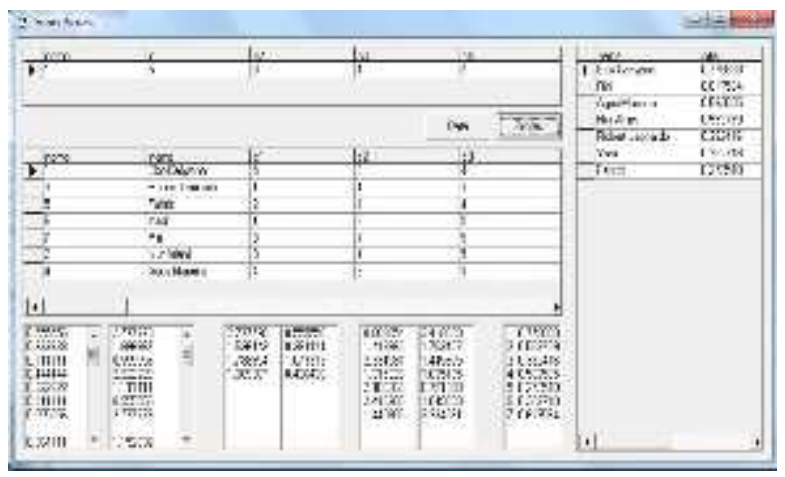

\subsection{Tampilan Form Data Karyawan}

Gambar 3. Form Seleksi Karyawan

Form Data Karyawanmerupakan tampilan antarmuka untuk menginput data karyawan yang akan diseleksi. Berikut adalah form data karyawan, dapat dilihat pada gambar 4:

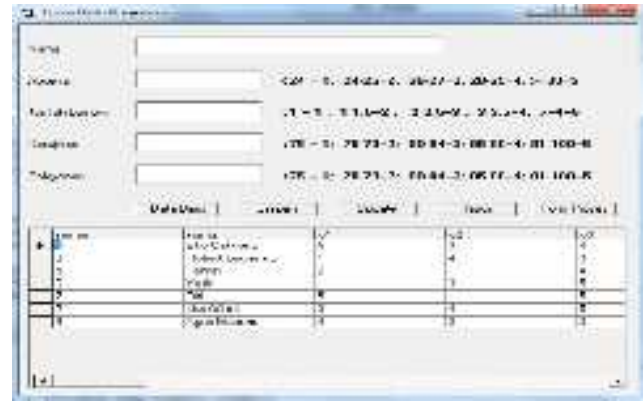

Gambar 4. Form Data Karyawan

\subsection{Pengujian Sistem}

Pengujian dilakukan dengan membandingkan perhitungan secara manual dan sistem aplikasi.

\subsubsection{Data Nilai Karyawan Restoran KL Express}

Data inputan ini adalah daftar sebagian nama karyawan restoran KL Express beserta kelengkapan data kriteria untuk pengujian. Berikut merupakan data nilai karyawan, dapat dilihat pada tabel 2 : 
Tabel 2. Data Nilai Karyawan KL Express

\begin{tabular}{|c|c|c|c|c|c|}
\hline \multirow{2}{*}{ No } & \multirow{2}{*}{ INama } & \multirow{2}{*}{ AbsensI } & Jumlah lcmbur & \multirow{2}{*}{ Kerajinan } & \multirow{3}{*}{$\begin{array}{c}\text { Fulovoridi } \\
\text { Customer } \\
75\end{array}$} \\
\hline & & & [Dalem Satu Bulan] & & \\
\hline 1 & Eku Cahipono & 30 & 2 & 86 & \\
\hline 2 & Nur nfiani & 27 & 3,5 & 92 & 79 \\
\hline 3 & Robert Leonardo & 23 & 3 & 31 & 81 \\
\hline 4 & Azus Varisno & 28 & 2.5 & 33 & 72 \\
\hline 5 & Fahrlzl & 25 & 1,5 & BI & 77 \\
\hline 6 & Yasir & 23 & 2 & $\mathrm{JI}$ & 13 \\
\hline 7 & Riri & 31 & 0 & 91 & 72 \\
\hline
\end{tabular}

\subsubsection{Data Konversi Seleksi Karyawan}

Berikut adalah data awal Karyawan yang dipilih yang sudah dikonversikan, dapat dilihat pada gambar 5:

\begin{tabular}{|c|c|c|c|c|c|}
\hline & $1 m^{-c}$ & $|c|$ & $c^{2}$ & $\therefore$ & ct \\
\hline b & $=k$ s aduerc & 5 & 3 & 4 & 2 \\
\hline & Yus oliari & 3 & 2 & 5 & 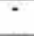 \\
\hline & 3obatLesids & - & i & ह & 3 \\
\hline & 约 & 4 & 3 & 5 & $\cdot$ \\
\hline & $=3$ Glie & 2 & 1 & 4 & 2 \\
\hline & iosir & - & J & 5 & 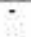 \\
\hline & Fir & 5 & 1 & E & - \\
\hline
\end{tabular}

Gambar 5. Data Konversi

Berikut adalah nilai variable dari karyawan KL Express yang telah dikonversi dari nilai awal menjadi nilai angka, dapat dilihat pada tabel 3 :

Tabel 3.Tabel Konversi Data

\begin{tabular}{|c|c|c|}
\hline Kriteria & Data Awal & Konversi \\
\hline \multirow[t]{5}{*}{ Absensi } & $<24$ & 1 \\
\hline & $24-25$ & 2 \\
\hline & $26-27$ & 3 \\
\hline & $28-29$ & 4 \\
\hline & $>29$ & 5 \\
\hline \multirow{5}{*}{$\begin{array}{l}\text { Jumlah Lembur } \\
\text { (Dalam Satu Bulan) }\end{array}$} & $<1$ & 1 \\
\hline & $1-1,5$ & 2 \\
\hline & $2-2,5$ & 3 \\
\hline & $3-3,5$ & 4 \\
\hline & $>=4$ & 5 \\
\hline \multirow[t]{7}{*}{ Hasil Tes Jurnais } & $<75$ & 1 \\
\hline & $75-79$ & 2 \\
\hline & $80-84$ & 3 \\
\hline & $85-90$ & 4 \\
\hline & $91-100$ & 5 \\
\hline & $<75$ & 1 \\
\hline & $75-79$ & 2 \\
\hline \multirow[t]{3}{*}{ Pelayanan Customer } & $80-84$ & 3 \\
\hline & $85-90$ & 4 \\
\hline & $91-100$ & 5 \\
\hline
\end{tabular}


Adapun yang diuji adalah kriteria yang keempat, yaitu nilai dari pelayanan terhadap customer. Kemudian data matriks yang sudah dikonversi dinormalisasikan:

\section{A. Matriks Keputusan Ternormalisasi}

Langkah selanjutnya yaitu membuat matriks keputusan yang ternormalisasi.

$$
\begin{aligned}
& \left|x_{q}\right|=\sqrt{2^{2}+1^{2}+3^{2}+1^{2}+2^{2}+1^{2}+1^{2}}=4,582576 \\
& r_{1}=\frac{x_{1}}{\left|x_{q}\right|}=\frac{2}{4,582576}=0,436436 \\
& r_{2}=\frac{x_{2}}{\left|x_{q}\right|}=\frac{1}{4,582576}=0,218218 \\
& r_{3}=\frac{x_{3}}{\left|x_{q}\right|}=\frac{3}{4,582576}=0,654654 \\
& r_{4}=\frac{x_{4}}{\left|x_{q}\right|}=\frac{1}{4,582576}=0,218218 \\
& r_{5}=\frac{x_{5}}{\left|x_{q}\right|}=\frac{2}{4,582576}=0,436436 \\
& r_{6}=\frac{x_{6}}{\left|x_{q}\right|}=\frac{1}{4,582576}=0,218218 \\
& r_{7}=\frac{x_{7}}{\left|x_{q}\right|}=\frac{1}{4,582576}=0,218218
\end{aligned}
$$

Dari matriks keputusan yang ternormalisasi, maka diperoleh nilai matriks pada kolom keempat sebagai berikut :

$$
K_{\mathrm{ki}} \quad \text { q }=\left\{\begin{array}{c}
0,436436 \\
0,218218 \\
0,654654 \\
0,218218 \\
0,436436 \\
0,218218 \\
0,218218
\end{array}\right\}
$$

Berikut adalah hasil proses perhitungan dari aplikasi kriteria keempat, dapat dilihat pada gambar yang dilingkari pada gambar 6 :

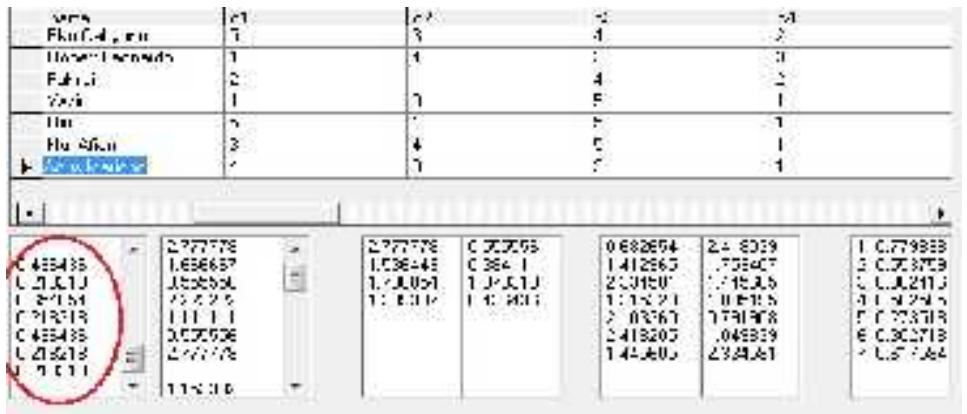

Gambar 6. Matriks Keputusan Ternormalisasi

\section{B. Matriks Keputusan Ternormalisai Terbobot}

Menghitung matriks keputusan yang ternormalisasi terbobot pada kolom keempat . Dimana untuk menghitung matriks ternormalisasi terbobot, (Data Normalisasi) x (Bobot Kriteria) sebagai berikut:

Sehingga diperoleh matriks $y_{k i}$

$$
\begin{aligned}
& y_{1}=w_{4} \cdot r_{1}=(2)(0,436436)=0,872872 \\
& y_{2}=w_{4} \cdot r_{2}=(2)(0,218218)=0,436436 \\
& y_{3}=w_{4} \cdot r_{3}=(2)(0,654654)=1,309308 \\
& y_{4}=w_{4} \cdot r_{4}=(2)(0,218218)=0,436436 \\
& y_{5}=w_{9} \cdot r_{5}=(2)(0,436436)=0,872872 \\
& y_{6}=w_{4} \cdot r_{6}=(2)(0,218218)=0,436436 \\
& y_{7}=w_{4} \cdot r_{7}=(2)(0,218218)=0,436436
\end{aligned}
$$




$$
y_{k i} \quad=\left\{\begin{array}{cccc}
0,872872 & 0,436436 & 1,309308 & 0,436436 \\
0,872872 & 0,436436 & 0,436436
\end{array}\right\}
$$

Berikut hasil proses perhitungan dari aplikasi kriteria keempat, dapat dilihat pada gambar yang dilingkari pada gambar 7 :

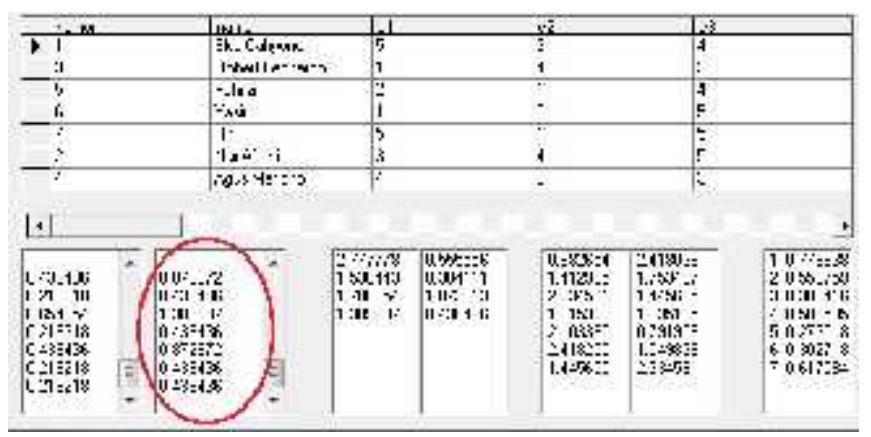

Gambar 7. Matriks Keputusan Ternormalisasi Terbobot

C. Matriks Solusi Ideal Positif dan Matriks Solusi Ideal Negatif

Solusi ideal dan negatif $\left(\mathrm{A}^{+}\right),\left(\left(\mathrm{A}^{-}\right)\right.$dihitung berdasarkan persamaan sebagai berkut:

$$
\begin{aligned}
& \left(\mathrm{A}^{+}=\left(\mathrm{y}_{1}{ }^{+} \mathrm{y}_{2}{ }^{+}, \ldots,\left(\mathrm{y}_{\mathrm{n}}{ }^{+}\right)\right.\right. \\
& \left(\mathrm{A}^{-}=\left(\mathrm{y}_{1}{ }^{-} \mathrm{y}_{2}{ }^{-}, \ldots,\left(\mathrm{y}_{\mathrm{n}}{ }^{-}\right)\right.\right.
\end{aligned}
$$

\section{Matriks Solusi Ideal Positif}

$$
\begin{aligned}
& \mathrm{y}_{\mathrm{A}}{ }^{+}=\max \left\{\begin{array}{cc}
\mathbf{Z}, \mathbf{7} & 1,6666650,5555552,22222 \\
& 1,111110,555555 \mathbf{Z}, \mathbf{7}
\end{array}\right\} \\
& =2,77778 \\
& \mathrm{y}_{2}{ }^{+}=\max \left\{\begin{array}{ccc}
1,152333 \mathbf{1 , 5} & , \mathbf{5} & 1,152333 \\
0,384111 & 1,152333 & 0,384111
\end{array}\right\} \\
& =1,536444 \\
& \mathrm{y}_{3}{ }^{+}=\max \left\{\begin{array}{ccc}
1,431084 \mathbf{1}, 7 & 1,073312 & 1,073212 \\
1,431084 \mathbf{1}, 7 & , 7
\end{array}\right\} \\
& =1,788856
\end{aligned}
$$

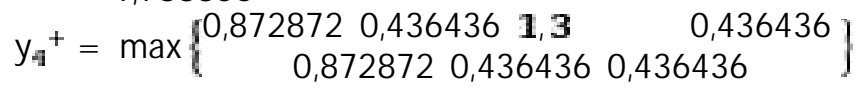

$$
\begin{aligned}
& =1,309308
\end{aligned}
$$

Sehingga diperoleh Solusi Ideal Positif $\left(\mathrm{A}^{+}\right)$sebagai berikut: $\boldsymbol{y}^{+}=\left\{\begin{array}{llll}2,77778 & 1,536444 & 1,788856 & 1,309308\end{array}\right\}$

2. Matriks Solusi Ideal Negatif

$$
\begin{aligned}
& \mathrm{y}_{\mathbf{1}}{ }^{-}=\min \left\{\begin{array}{cc}
2,777781,666665 \mathbf{0 , 5} & 2,22222 \\
1,11111 \mathbf{0 , 5} & 2,77778
\end{array}\right\} \\
& =0,555555
\end{aligned}
$$

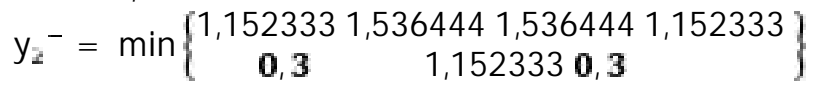

$$
\begin{aligned}
& =0,384111 \\
& \mathrm{y}_{3}{ }^{-}=\min \left\{\begin{array}{rr}
1,4310841,788856 \mathbf{1 , 0} & , \mathbf{0} \\
1,4310841,788856 & 1,788856
\end{array}\right\} \\
& =1,073312 \\
& \left.\begin{array}{rl}
\mathrm{y}_{\mathbf{q}^{-}}{ }^{-} & =\min \left\{\begin{array}{cc}
0,872872 \mathbf{0 , 4} & 1,309308 \mathbf{0 , 4} \\
0,872872 \mathbf{0 , 4} & \mathbf{0 , 4}
\end{array}\right\} \\
& =0,436436
\end{array}\right\}
\end{aligned}
$$

Sehingga diperoleh Solusi Ideal Positif $\left(\mathrm{A}^{-}\right)$sebagai berikut: $\boldsymbol{y}^{-}=\left\{\begin{array}{llll}0,555555 & 0,384111 & 1,073312 & 0,436436\end{array}\right\}$ 
Tabel 4. Hasil Solusi Ideal Positif dan Solusi Negatif

\begin{tabular}{|l|l|l|}
\hline No & Max & Min \\
\hline 1 & 2,77778 & 0,555555 \\
\hline 2 & 1,536444 & 0,384111 \\
\hline 3 & 1,788856 & 1,073312 \\
\hline 4 & 1,309308 & 0,436436 \\
\hline
\end{tabular}

Berikut hasil proses perhitungan solusi ideal positif dan negative, dapat dilihat pada gambar yang dilingkari pada gambar 8:

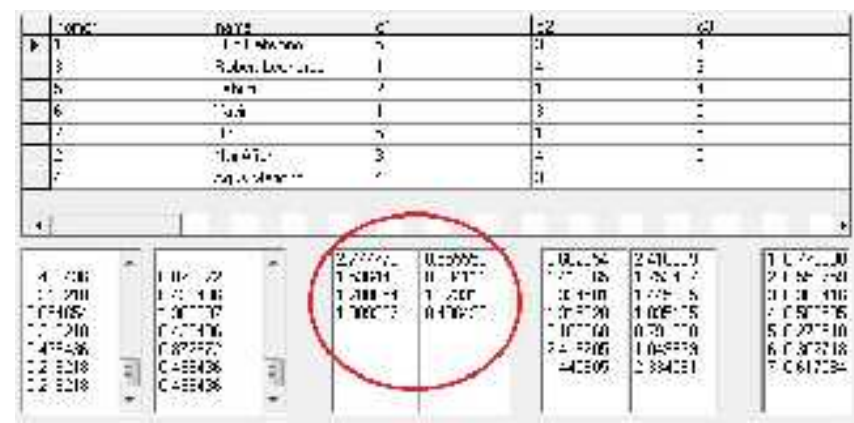

Gambar 8. Solusi Ideal Positif dan Solusi Ideal Negatif

D. Menentukan Jarak Setiap Alternatif dengan Matriks Solusi Ideal Positif

Untuk mencari jarak antara nilai terbobot pada setiap alternatif terhadap solusi ideal positif $\left(\mathrm{s}_{\overline{1}}{ }^{+}\right)$ dirumuskan sebagai :

$$
\begin{aligned}
& L_{\mathrm{L}}^{+}=\sqrt{\sum_{j=1}^{n}\left(y_{j}^{+}-y_{\mathrm{L}}\right)^{2}} \\
& \text { Dimana } y_{j}=N \quad M \quad Y \text { : } \\
& y_{\mathrm{L}}=N \quad S \quad l l \quad m \quad P \\
& \left(D_{1}{ }^{+}\right)=\sqrt{\begin{array}{l}
(2,77778-2,77778)^{2}+(1,152333-1,536444)^{2}+ \\
(1,431084-1,788856)^{2}+(0,872872-1,309308)^{2}
\end{array}} \\
& =0,682655 \\
& \left(D_{2}{ }^{+}\right)=\sqrt{\begin{array}{l}
(1,666665-2,77778)^{2}+(1,536444-1,536444)^{2}+ \\
(1,788856-1,788856)^{2}+(0,436436-1,309308)^{2}
\end{array}} \\
& =\quad 1,412969 \\
& \left(D_{3}{ }^{+}\right)=\sqrt{\begin{array}{l}
(0,555555-2,77778)^{2}+(1,536444-1,536444)^{2}+ \\
(1,073312-1,788856)^{2}+(1,309308-1,309308)^{2}
\end{array}} \\
& =\quad 2,334585 \\
& \left(\mathrm{D}_{q}{ }^{+}\right)=\sqrt{\begin{array}{l}
(2,22222-2,77778)^{2}+(1,152333-1,536444)^{2}+ \\
(1,073312-1,788856)^{2}+(0,436436-1,309308)^{2}
\end{array}} \\
& =1,315331 \\
& \left(D_{5}{ }^{+}\right)=\sqrt{\begin{array}{l}
(1,11111-2,77778)^{2}+(0,384111-1,536444)^{2}+ \\
(1,431084-1,788856)^{2}+(0,872872-1,309308)^{2}
\end{array}} \\
& =\quad 2,103363 \\
& \left(\mathrm{D}_{\bar{\sigma}}{ }^{+}\right)=\sqrt{\begin{array}{l}
(0,555555-2,77778)^{2}+(1,152333-1,536444)^{2}+ \\
(1,788856-1,788856)^{2}+(0,436436-1,309308)^{2}
\end{array}}
\end{aligned}
$$




$$
\begin{aligned}
& =\frac{2,418208}{\left(\mathrm{D}_{l}^{+}\right)}=\sqrt{\begin{array}{l}
(2,77778-2,77778)^{2}+(0,384111-1,536444)^{2}+ \\
(1,788856-1,788856)^{2}+(0,436436-1,309308)^{2}
\end{array}} \\
& =\quad \begin{array}{l}
1,445606
\end{array}
\end{aligned}
$$

Sehingga diperoleh jarak antara nilai terbobot pada setiap alternatif ideal positif sebagai berikut:

$$
D^{+}=\left\{\begin{array}{l}
0,682655 \\
1,412969 \\
2,334585 \\
1,315331 \\
2,103363 \\
2,418208 \\
1,445606
\end{array}\right\}
$$

Berikut hasil proses perhitungan dari aplikasi kriteria kelima, dapat dilihat pada gambar 9 :

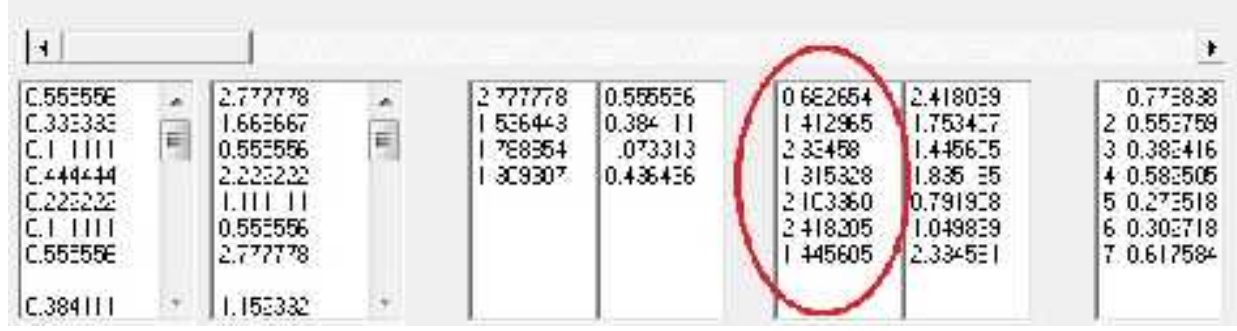

Gambar 9. Alternatif Terhadap Solusi Ideal Positif

E. Menentukan Nilai Preferensi untuk Setiap Alternatif

$$
\begin{aligned}
& V_{1}=\frac{D_{1}^{-}}{D_{1}^{-}+D_{1}^{+}}=\frac{2,418042}{2,418042+0,682655}=0,779838 \\
& V_{4}=\frac{D_{2}^{-}}{D_{2}^{-}+D_{2}^{+}}=\frac{1,753408}{1,753408+1,412969}=0,553758 \\
& V_{3}=\frac{D_{3}^{-}}{D_{3}^{-}+D_{3}^{+}}=\frac{1,445606}{1,445606+2,334585}=0,382416 \\
& V_{q}=\frac{D_{q}^{-}}{D_{q}^{-}+D_{\mathrm{q}}^{+}}=\frac{1,835194}{1,835194+1,315331}=0,582504 \\
& V_{5}=\frac{D_{5}^{-}}{D_{5}^{-}+D_{5}^{+}}=\frac{0,791908}{0,791908+2,103363}=0,273518 \\
& V_{5}=\frac{1,049482}{D_{5}^{-}}=\frac{2, D_{6}^{+}}{1,049482+2,418208}=0,302646 \\
& V_{l}=\frac{D_{1}^{-}}{D_{1}^{-}+D_{1}^{+}}=\frac{2,334585}{2,334585+1,445606}=0,617584
\end{aligned}
$$

Sehingga diperoleh nilai preferensi setiap alternatif $\left(\mathrm{V}_{\mathbf{i}}\right)$ sebagai berikut:

$$
V_{\mathrm{L}}=\left\{\begin{array}{c}
0,779838 \\
0,553758 \\
0,382416 \\
0,582504 \\
0,273518 \\
0,302646 \\
0,617584
\end{array}\right\}
$$

Dari nilai $\mathrm{V}$ ini dapat dilihat bahwa $V_{1}$ memiliki nilai terbesar, sehingga alternatif pertama akan terpilih sebagai karyawan KL Express yang mendapat gaji bonus. Berikut adalah nilai akhir, dapat dilihat pada gambar 10 : 


\begin{tabular}{|c|c|c|}
\hline & noms & nizi \\
\hline 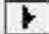 & בk: & 0.779090 \\
\hline & Hri & 0.51/58.1 \\
\hline & Ryux Meioun & 0.732505 \\
\hline & Nur Aliani & $0.553^{7} 59$ \\
\hline & Rinhent I arnarin & ก $33>41 \mathrm{~h}$ \\
\hline & Yosii & $0.372^{3710}$ \\
\hline & tahrz & U. $2 / 3 b 18$ \\
\hline
\end{tabular}

Gambar 10. Nilai Preferensi untuk Setiap Alternatif

\subsection{Perbandingan Perhitungan Sistem Terdahulu dan Sistem Baru}

Pada sistem terdahulu restoran KL Express di dalam penilaian wartawan adalah dengan menggunakan sistem menghitung rata - rata. Berikut adalah data karyawan KL Express, dapat dilihat pada tabel 5 :

Tabel 5. Data Karyawan KL Express

\begin{tabular}{|c|c|c|c|c|c|}
\hline \multirow{2}{*}{ No } & \multirow{2}{*}{ Nama } & \multirow{2}{*}{ Absensl } & Jumlah lembur & \multirow{2}{*}{ KErajInan } & Fuloyould \\
\hline & & & [Dalem Satu Bulan) & & Customer \\
\hline 1 & Eku Catiyonu & 30 & 2 & 36 & 75 \\
\hline 2 & Nur $A$ fianl & 27 & 3,5 & 92 & 79 \\
\hline 3 & Riobert Leonardo & 22 & 3 & 31 & 81 \\
\hline 4 & Azus Varieno & 28 & 2.5 & 33 & 72 \\
\hline 5 & Fahrlal & 25 & 1,5 & 37 & 77 \\
\hline 6 & Ya51r & $z$ & 2 & $\mathrm{~J}$ & is \\
\hline 7 & Riri & 31 & 0 & 91 & 72 \\
\hline
\end{tabular}

Dari data pada tabel 6 cara perhitungannya sebagai berikut:

Tabel 6. Hasil Perbandingan Perhitungan

\begin{tabular}{|c|l|c|c|c|c|}
\hline No & \multicolumn{1}{|c|}{ Nama } & H Lama & H Baru & R Lama & R Baru \\
\hline 1 & Nur Afiani & 49,1 & 0,553 & 1 & 4 \\
\hline 2 & Eko Cahyono & 48,5 & 0,779 & 2 & 1 \\
\hline 3 & Riri & 48,5 & 0,617 & 3 & 2 \\
\hline 4 & Fahrizi & 47,6 & 0,273 & 4 & 7 \\
\hline 5 & Yasir & 47,2 & 0,302 & 5 & 6 \\
\hline 6 & Robert Leonardo & 47 & 0,382 & 6 & 5 \\
\hline 7 & Agus Mariono & 46,4 & 0,582 & 7 & 3 \\
\hline
\end{tabular}

\section{Keterangan :}

- H Lama : Perhitungan manual (dengan menggunakan rata-rata)

- H Baru : Perhitungan menggunakan metode topsis

- R Lama : Perangkingan hasil perhitungan manual

- R Baru : Perangkingan hasil perhitungan metode topsis

Dari tabel 6, dapat dianalisis perbandingan urutan perhitungan menggunakan cara manual (yang selama ini dilakukan KL Express) dan perhitungan menggunakan metode TOPSIS. Pada data tabel diatas terdapat perbedaan urutan karyawan yang mendapat gaji bonus, perbedaan ini disebabkan karena perhitungan dengan sistem memberikan nilai prioritas dengan memberikan bobot pada setiap kriteria.

\section{KESIMPULAN}

Berdasarkan hasil dan pembahasan, maka kesimpulan yang dapat kita ambil adalah sebagai berikut :

1. Karyawan dengan urutan paling atas dalam tabel adalah karywan yang memiliki nilai paling tinggi dan berhak mendapatkan gaji bonus.

2. Sistem Pendukung Keputusan dengan menggunakan metode TOPSIS dapat menghasilkan nilai rangking karyawan dalam seleksi pemberian gaji bonus pada restoran KL Express . 


\section{DAFTAR PUSTAKA}

[1] Kristanto, Andi. 2008. Perancangan Sistem Informasi dan Apilkasinya. Yogyakarta. Gava Media.

[2] Turban, Efraim, et al. 2005. Decision Support Systems and Intelligent Systems .7th Ed. New Jersey. Pearson Education.

[3] Keen, P. G. W. 1980. Adaptive Design for Decision Support Systems, Data Base, Vol. 12, No. 1 dan 2. 